2. Current Concerns in the Chemotherapy of Leprosy

(A) Monotherapy 



\title{
Viability of Myco. leprae in the Skin and Bone Marrow of Patients with Lepromatous Leprosy While on Dapsone or Lamprene
}

\author{
A. B. A. KARAT \\ St. Catherine's Hospital, Birkenhead, U.K.
}

\begin{abstract}
The pattern of killing of Myco. leprae in the skin and bone marrow of untreated lepromatous leprosy patients was studied after initiation of specific treatment with dapsone $100 \mathrm{mg}$ daily ( 5 patients) as compared with clofazimine $100 \mathrm{mg}$ daily ( 5 patients). It was found that while both clofazimine and dapsone appear to be equally effective in killing Myco. leprae in the skin, bacilli remained viable in the bone marrow long after they ceased to be viable in the skin, in 4 patients ( 2 on dapsone and 2 on clofazimine) after 720 days. The implications of this in relation to relapse/recrudescence are discussed, and the usefulness of the mouse model in providing information of value to the clinician is emphasized.
\end{abstract}

\section{Introduction}

It has been fairly widely accepted that Myco. leprae multiply better in the cooler parts of the body. The persistence of Myco. leprae in the reticulo-endothelial system (e.g. liver and bone marrow) af ter their disappearance from the skin casts some doubts on this hypothesis (Karat, 1966; Karat et al., 1971). It was further demonstrated that Myco. leprae in the liver and bone marrow were not effete organisms but viable and able to multiply in the footpads of mice.

A prospective study was therefore undertaken to determine the pattern of killing of Myco. leprae in the skin and bone marrow of untreated lepromatous leprosy patients after initiation of specific treatment with dapsone $100 \mathrm{mg}$ daily and compare it with patients on Lamprene $100 \mathrm{mg}$ daily.

\section{Materials and Methods}

Consecutive patients with untreated lepromatous leprosy and B.I. more than $3+$ (Ridley, 1964) were randomly allocated to 2 therapy groups:

I To receive $100 \mathrm{mg}$ dapsone daily orally

II To receive $100 \mathrm{mg}$ Lamprene daily orally.

Skin biopsy and bone marrow aspiration were obtained on day " 0 " and every 90 days thereafter for two years. The skin biopsy and bone marrow aspirate were homogenized in the usual way to obtain Myco. leprae in suspension and 5000 Мусо. leprae were innoculated into the hind footpads of thymectomized C.B.A. 
mice. These mice were harvested at regular intervals and harvest counts of Myco. leprae were obtained.

Of the 15 patients who entered the study 5 dropped out and results presented here in relation to the remaining 10 patients ( 5 on dapsone and 5 on Lamprene).

\section{Results}

\section{Dapsone treated patients}

The viability of Myco. leprae in the skin and bone marrow aspirate of dapsone treated patients is shown in Table 1 .

TABLE 1

Viability of Myco. leprae in skin and bone marrow of dapsone treated patients

\begin{tabular}{|c|c|c|c|c|c|c|c|c|c|c|}
\hline \multirow[t]{2}{*}{ No. of days } & \multicolumn{2}{|c|}{1} & \multicolumn{2}{|c|}{ II } & \multicolumn{2}{|c|}{ III } & \multicolumn{2}{|c|}{ IV } & \multicolumn{2}{|c|}{$\mathrm{V}$} \\
\hline & $\mathrm{S}^{a}$ & $\mathrm{BM}^{b}$ & $\mathrm{~S}$ & $\mathrm{BM}$ & S & BM & S & BM & S & BM \\
\hline 0 & + & + & + & + & + & + & + & + & + & + \\
\hline 90 & - & + & + & + & + & + & + & + & - & + \\
\hline 180 & - & + & - & + & + & + & - & + & - & + \\
\hline 270 & - & - & _- & + & _- & + & - & + & - & + \\
\hline 360 & - & - & - & + & - & + & - & + & - & + \\
\hline 450 & - & - & - & - & - & + & - & + & - & + \\
\hline 540 & - & - & - & - & - & + & - & + & - & + \\
\hline 630 & - & - & - & - & - & + & - & - & - & + \\
\hline 720 & - & - & - & - & - & + & - & - & - & + \\
\hline
\end{tabular}

Between 90 and 270 days (3 to 9 months) Myco. leprae in the skin were non-viable in the footpads of mice. The Myco. leprae from bone marrow remained viable in 2 cases at the end of 2 years; in one they were non-viable at 9 months, in another at 15 months and in the third at 21 months.

\section{Lamprene treated patients}

The viability of Myco. leprae in the skin and bone marrow aspirate of Lamprene treated patients is shown in Table 2.

Myco. leprae in the skin became non-viable in 180 to 360 days (6 to 12 months) and those in the bone marrow aspirate in 3 cases at 360, 450 and 540 days (12, 15 and 18 months) respectively. In 2 cases they remained viable at the end of 2 years.

\section{Comments}

Both Lamprene and dapsone appear to be equally effective in killing Myco. leprae in the skin of lepromatous leprosy patients when administered orally in a 
TABLE 2

Viability of Myco. leprae in skin and bone marrow of Lamprene treated patients

\begin{tabular}{ccccccccccccc}
\hline No. of days & \multicolumn{1}{c}{ I } & \multicolumn{1}{c}{ II } & \multicolumn{1}{c}{ III } & \multicolumn{3}{c}{ IV } & & V \\
& S & BM & S & BM & S & BM & S & BM & S & BM \\
\hline 0 & + & + & + & + & + & + & + & + & + & + \\
90 & + & + & + & + & + & + & + & + & + & + \\
180 & - & + & - & + & + & + & + & + & - & + \\
270 & - & + & - & + & + & + & - & + & - & + \\
360 & - & + & - & + & - & + & - & - & - & + \\
450 & - & - & - & + & - & + & - & - & - & + \\
540 & - & - & - & - & - & + & - & - & - & + \\
630 & - & - & - & - & - & + & - & - & - & + \\
720 & - & - & - & - & - & + & - & - & - & + \\
\hline
\end{tabular}

dose of $100 \mathrm{mg}$ daily. The leprosy bacilli in the skin of lepromatous leprosy patients appear to be very sensitive to orally administered dapsone and Lamprene.

By contrast Myco. leprae in human bone marrow appear to be relatively refractory to orally administered dapsone and Lamprene, remaining viable in the bone marrow long after they have ceased to be viable in the skin. This could be either due to the inaccessibility of Myco. leprae in the bone marrow to the action of these drugs or because the drugs do not attain the required lethal level of concentration in the bone marrow. The latter is not the case as far as dapsone is concerned since the blood level of dapsone and the level of dapsone in the bone marrow aspirate were comparable in these patients. On the other hand it is conceivable that the environment of the bone marrow may be more conducive for the multiplication of Myco. leprae despite the known higher temperature of the bone marrow in man.

If in fact Myco. leprae not only persist in the bote marrow longer than in the skin but also remain viable in the bone marrow longer than in the skin, this has far-reaching therapeutic and clinical significance. These "persisters" among Myco. leprae in man could explain the rather high rate of relapse/recrudescence of leprosy among bacillated types of leprosy patients following premature cessation of specific therapy. Thus prolonged uninterrupted specific therapy becomes mandatory in bacillated types of leprosy in order to reduce the possibility of relapse/recrudescence of leprosy. The problem of persisters also raises a query as to the merits of monotherapy and polytherapy of leprosy with 2 or more drugs given simultaneously. Further longitudinal studies along these lines are indicated.

Once again the footpads of mice have provided very valuable information regarding the behaviour of Myco. leprae in man, which enables the clinician to make rational therapeutic desisions.

\section{Acknowledgements}

This work was sponsored by Radda Barnen, Stockholm and Ciba-Geigy, Basle. I am grateful to Mr Rajan Albert for technical assistance and all the junior doctors who have worked in my department and assisted me in obtaining specimens from the patients and in the continuing care of these patients. 


\section{References}

Ridley, D. S. (1964). Leprosy in Theory and Practice 2nd ed. (Eds. R. G. Cochrane and T. F. Davey) p. 620. Bristol: John Wright \& Sons Ltd.

Karat, A. B. A., Job, C. K., Rao, P. S. S. (1971). Brit. med. J. 1, 307.

Karat, A. B. A. (1966). Int. J. Lepr. 34, 415. 